DOI: $10.21802 / \operatorname{artm} .2020 .1 .13 .28$.

УДК 616-001.5+615.8

\title{
АНАЛІЗ ВПЛИВУ ПРОГРАМИ ФІЗИЧНОЇ ТЕРАПІЇ НА ПОКАЗНИКИ ФУНКЦІОНУВАННЯ ПЕРЕДПЛІЧЧЯ ТА КИТИЦІ У ХВОРИХ $З$ ПОСТІММОБІЛІЗАЦІЙНИМИ КОНТРАКТУРАМИ ПРОМЕНЕВО-ЗАП'ЯСТКОВОГО СУГЛОБА
}

\author{
В.М. Бирчак
}

Прикарпатський начіональний університет імені Василя Стефаника, кафедра фізичної терапії, ерготерапї̈, м. Івано-Франківськ, Украӥна,

ORCID ID: 0000-0001-8424-4923, e-mail:vmbyrchak@gmail.com

Резюме. Цілі: визначення ефективності розробленої програми фізичної терапії за результатами параметрів функціонування передпліччя та китиці у хворих з постіммобілізаційними контрактурами променевозап'ясткового суглоба (ПЗС).

Методи. Обстежено 56 осіб з постіммобілізаційною контрактурою ПЗС. Їх було поділено на дві групи: контрольну (займались згідно принципів поліклінічної реабілітації) та групу порівняння (займались за розробленою програмою фізичної терапії - комбінація теплого вологого компресу у поєднанні із постізометричною релаксацією м'язів передпліччя та китиці; масаж китиці, ПЗС, передпліччя, плеча; функціональне тренування передпліччя, китиці; лікування положенням за допомогою динамічних ортезів; кінезіологічне тейпування. Ефективність програми оцінювали за допомогою порівняння стану здорової та травмованої рук за результатами Тесту дослідження функцій руки (Action Research Arm Test) та Тесту для руки Френчай (Frenchay Arm Test).

Результати. При визначенні динаміки субтестів Тесту дослідження функцій руки визначено статистично значуще покращення параметрів основної групи відносно вихідних показників та даних групи порівняння $(\mathrm{p}<0,05)$. За субтестами циліндричного та щипкового захоплення вдалося досягнути величин здорової руки. Пацієнти основної групи також продемонстрували покращення функціонування руки у порівнянні з вихідним тестуванням та параметрами групи порівняння за всіма проведеними завданнями Тесту Френчай ( $<<0,05)$.

Висновки. Розроблена комплексна програма фізичної терапії виявила статистично значуще кращий вплив на показники функціонування передпліччя та китиці на основі результатів тестів дослідження функцій руки та Франчай у порівнянні із поліклінічною реабілітаційною програмою.

Ключові слова: реабілітація, перелом кістки, верхня кінцівка.

Вступ. Рука, в силу специфіки своєї функції як органу праці та тонких координованих рухів, але, в той же час, відкритої частини людського тіла, досить часто підлягає різним травмам. Ще у XIX столітті M.I. Пирогов зазначав, що «немає жодної частини тіла, у якій ушкодження були б так нескінченно різноманітні по виду, ступеню ушкоджень і наслідкам, як рука й нижня частина передпліччя». За даними сучасної медичної статистики, ушкодження рук посідає друге місце серед травм опорно-рухового апарата (76,3\%), при цьому в $31-48 \%$ випадків вони приводять до стійкої втрати працездатності $[1,7,8]$.

За даними літературних джерел, 76-86\% осіб працездатного віку отримують ушкодження дистальних відділів верхньої кінцівки різного ступеня важкості. Соціальна неспроможність цього контингенту хворих головним чином залежить від обмеження можливостей професійно-трудової діяльності: зниження кваліфікації, обмеження можливості навчання й перенавчання, неможливості працювати за спеціальністю $[13,14,16]$.

Найчастішим ускладненням цих ушкоджень $€$ посттравматичні контрактури суглобів, серед яких провідне місце займають постіммобілізаційні, що можуть призвести до інвалідності. Найбільші труднощі реабілітації викликають контрактури внаслідок поліструктурних ушкоджень верхньої кінцівки з ура- женням кісток, сухожилків нервів, судин, що становлять $31-57$ \% всіх травм кінцівок $[15,16]$.

Лікування та реабілітація травм верхніх кінцівок є складним не тільки медичним, а й соціальноекономічним завданням. Застосовувані на даний момент методи відновлення вимагають тривалих термінів госпіталізації та призводять до тривалої непрацездатності та великого відсотку виходу постраждалих на інвалідність, що призводить до значних економічних витрат суспільства і є тягарем для будь-якої системи медицини $[2,4,17]$.

Обгрунтування дослідження. Крім лікування наслідків самої травми у вигляді регенерації анатомічної цілісності пошкоджених структур, величезне значення має відновлення порушених функцій кінцівки. Навчання навичкам самообслуговування, повернення хворого до роботи має велике соціальноекономічне значення для суспільства. Отже, особливостями довготермінових цілей реабілітації при травмах дистальних відділів верхніх кінцівок $\epsilon$ обов'язкове максимально повноцінне відновлення дрібної моторики засобами фізичної терапії (ФТ), що напряму визначає якість життя пацієнта та перспективи його подальшої соціалізації $[3,7,10]$.

Особи з наслідками ушкоджень суглобів передпліччя та китиці мають високий реабілітаційний потенціал, який може бути реалізований шляхом 
функціональної ФТ. Комплексне відновлення стану здоров'я хворих 3 ушкодженнями променевозап'ясткового суглоба (ПЗС) дозволяє відновити працездатність у колишній професії й знизити групу інвалідності $[15,18]$.

Незважаючи на значну кількість існуючих програм відновлення функціонального стану дистальних відділів руки після травм $[6,17,18,21,23]$, слід зазначити їх основні недоліки: недостатню ефективність, моральну та технічну застарілість, відсутність адаптації до сучасних поглядів на реабілітацію 3 позицій Міжнародної класифікації функціонування (МКФ) та реформування спеціалізованої медичної допомоги в Україні. Отже, створення нових програм ФТ для хворих травмами верхніх кінцівок $є$ актуальною проблемою сучасної реабілітаційної медицини.

Мета роботи: визначення ефективності розробленої програми фізичної терапії за результатами параметрів функціонування передпліччя та китиці у хворих з постіммобілізаційними контрактурами ПЗС. Матеріали і методи. В дослідженні прийняли участь 56 осіб з постіммобілізаційною контрактурою ПЗС. Пацієнтів було поділено на дві групи. Для осіб групи порівняння (ГП, 29 осіб - 16 чоловіків та 13 жінок віком 41,6 $\pm 4,7$ роки) була проведена відновна програма згідно принципів реабілітації при травмах передпліччя в ділянці ПЗС, рекомендованих до застосування у постімобілізаційному періоді у поліклінічнихумовах [20] (кінезітерапія, масаж, застосування преформованих фізичних факторів на ділянку ПЗС та м'язів передпліччя). Основну групу (ОГ, 27 осіб - 15 чоловіків, 12 жінок віком $38,1 \pm 3,4$ роки) склали особи, які проходили реабілітацію за розробленою програмою ФТ.

Критерії включення в групу дослідження:

- Ранній постіммобілізаційний період після консервативного або оперативного лікування ускладнених (відкритих та/або зі зміщенням, та/або багатоуламкових, та/або внутрішньосуглобових, які потребували металоостеосинтезу та/або скелетного витяжіння та/або мали ускладнений перебіг загоєння, що призвело до збільшення терміну іммобілізації більше, ніж 1,5 місяця) переломів кісток нижньої третини передпліччя;

- Наявність постіммобілізаційної контрактури ПЗС поліструктурного походження (внаслідок внутрішньосуглобових переломів з порушенням конгруентності суглобових поверхонь; пошкоджень капсульнозв'язкового апарату; первинних травматичних та вторинних постіммобілзаційних змін в м'язах; поєднані перераховані зміни);

- Критерії накладеної іммобілізації - циркулярна гіпсова пов'язка від основи пальців до середини або верхньої третини передпліччя;

- Інформована згода щодо участі у дослідженні;

- Інформована згода виконання наданих рекомендацій після ознайомлення з основними принципами розробленої програми ФТ (для осіб ОГ);

- Згода щодо обробки конфіденційної інформації.

Критерії виключення з групи дослідження:

- Наявність неускладнених та/або без значного зміщення переломів однієї або двох кісток передпліч- чя в нижній третині, що потребували стандартних термінів іммобілізації тривалістю до 1,5 місяця;

- Критерії накладеної іммобілізації - гіпсова пов'язка із захопленням ліктьового суглоба або суглобів фаланг пальців;

- Наявність ревматичного ураження або неврологічних порушень у ділянці травмованої або неушкодженої руки в анамнезі або на момент первинного обстеження;

- Відсутність згоди участі у дослідженні або щодо обробки конфіденційної інформації.

Розроблена програма ФТ впроваджувалась впродовж амбулаторно-поліклінічного етапу реабілітації, була поділена на три періоди:

1. щадний (2 тижні); проведені заходи:

- лімфодренажний масаж китиці, ПЗС, передпліччя, плеча;

- функціональне тренування передпліччя та китиці в полегшених умовах;

авторська комбінація застосування теплого вологого компресу на основі термопакету у поєднанні із постізометричною релаксацією м'язів передпліччя та китиці [19];

лікування положенням в досягнутих положеннях корекції за допомогою індивідуальних динамічних ортезів для ПЗС, виготовлених з низькотемпературного пластику;

кінезіологічне тейпування передпліччя, ПЗС, китиці із використанням лімфодренажної та послаблюючої технік.

2. щадно-тренуючий (3 тижні); проведені заходи:

щадний масаж китиці, ПЗС, передпліччя, плеча з елементами рухів у ПЗС;

авторська комбінація застосування теплого вологого компресу на основі термопакету у поєднанні iз постізометричною релаксацією м'язів передпліччя та китиці [10];

- електростимуляція м'язів передпліччя;

- функціональне тренування передпліччя та китиці із використанням тренажера для відновлення китиці «Pro Hand Trainer Thera-Band»;

кінезіологічне тейпування передпліччя та китиці із використанням м'язової та послаблюючої технік.

3. тренуючий (3 тижні); проведені заходи:

тонізуючий та вібраційний масаж китиці, ПЗС, передпліччя, плеча, з елементами рухів у ПЗС;

функціональне тренування м'язів передпліччя, китиці, плеча; вправи 3 опором та обтяженням (із використанням стрічкових та китичних тренажерів Thera-band, гіроскопічного тренажера Powerball);

кінезіологічне тейпування передпліччя та китиці із використанням м'язової та функціональної технік.

Перевагами розробленої програми є функціональний підхід на основі виявлених за допомогою представлених тестів змін; максимальна індивідуалізація за рахунок визначення коротко- та довготривалих цілей реабілітації; поєднання класичних та сучасних реабілітаційних методик; економічна доступність; легкість відтворення в умовах будь-якої реабілітаційної установи. 
У процесі дослідження застосовували батареї тестів, які дають можливість оцінити такі компоненти Міжнародної класифікації функціонування (МКФ) як стан структури та функції, а також тісно пов'язаний $з$ ними при травмах руки домен «Активність та участь».

Для визначення ступеня локальних функціональних порушень, які впливають на ступінь загального обмеження життєдіяльності організму за рахунок виконання повсякденних побутових дій (здатність захоплювати та утримувати різні предмети, спритність, гнучкість пальців, силу китиці) проводили Тест дослідження функцій руки (Action Research Arm Test) та Тест для руки Френчай (Frenchay Arm Test).

Тест дослідження функцій руки оцінював основні види побутової активності кисті (кульове захоплення, циліндричне захоплення, щипкове захоплення, грубі рухи руки). У кожному з субтестів (детальний зміст яких наведений у таблицях представленої статті) завдання були розташовані у певному порядку. Якщо пацієнт добре виконував перше завдання, не було необхідності виконувати наступні, отже ставили вищий за даним субтестом бал. Якщо випробуваний не міг виконати друге завдання, то не проводили наступні завдання даного субтеста. У всіх інших випадках виконували всі завдання субтесту. Кожне із завдань оцінювали у балах від 0 (невиконання) до 3 (найкраще виконання) [5, 22].

Оцінювання функції руки також проводили за тестом Френчай. Вихідне положення для виконання кожного завдання - сидячи за столом, руки лежать на колінах. Пацієнт виконував завдання ураженою рукою; за кожне успішно виконане завдання отримував 1 бал, за невиконане - 0 балів. Підраховували загальну кількість балів за тест [5, 22].

Ефективність розробленої програми ФТ оцінювали до та після впровадження за результатами порівняння стану здорової та травмованої верхньої кінцівки у кожного пацієнта.

Отримані дані обробляли статистично за допомогою програм «Microsoft Excel»5.0 та «Statistica» 6.0 for Windows. Розраховували середнє арифметичне значення $(\bar{x})$ та середнє квадратичне відхилення (S) показників. Для оцінки достовірності отриманих показників застосовувались критерії Стьюдента. Критичний рівень значимості при перевірці статистичних гіпотез у даному дослідженні приймали рівним 0,05 .

Результати дослідження. Аналіз результатів первинного обстеження виявив наступні закономірності.

При визначенні функціонального стану передпліччя та китиці за результатами Тесту дослідження функцій руки визначено, що найменшим порушенням в обох обстежуваних групах характеризувався субтест «Грубі рухи руки» $(\mathrm{p}<0,05$ відносно всіх проб здорової кінцівки) (табл. 1). Очевидно, це обгрунтовується тим, що цей рух переважно реалізується за рахунок збереженої функціональної діяльності плечового та ліктьового суглобів.

Всі інші компоненти тесту - кульове захоп- лення, циліндричне захоплення, щипкове захоплення - були значно погіршеними відносно відповідного показника здорової руки ( $>0,05)$, що свідчило про погіршення структури і функції дистальних відділів верхньої кінцівки при посттравматичних контрактуpax (табл. 1).

При обстеженні за Тестом функції руки Френчай визначено низькі функціональні спроможності дистальних відділів травмованих верхніх кінцівок, що проявлялось в ускладненні або неможливості виконання всіх тестових завдань (табл. 2).

Повторне обстеження пацієнтів 3 постіммобілізаційною контрактурою ПЗС показало значні переваги створеної програми ФТ.

Так, при визначенні динаміки субтестів Тесту дослідження функцій руки (Action Research Arm Test) визначено статистично значуще покращення параметрів ОГ не тільки відносно вихідних показників, але й даних ГП $(\mathrm{p}<0,05)$. Найкращою динамікою характеризувались субтести циліндричного та щипкового захоплення, за якими вдалося досягнути величин здорової руки (табл. 1).

Динаміка результатів Тесту функції руки Френчай також показала перевагу розробленої програми ФТ (табл. 2). У пацієнтів ГП хоча і була виявлена позитивна динаміка, проте вона не була вираженою, що підтверджує результати Тесту дослідження функцій руки. Пацієнти ОГ продемонстрували статистично значуще покращення функціонування руки у порівнянні 3 вихідним тестуванням та параметрами ГП за всіма проведеними тестами $(\mathrm{p}<0,05)$, що свідчить про покращення структури, функції ПЗС, побутової та професійної активності.

Обговорення результатів. Аналіз сучасних літературних даних $[2,6,9]$ показує, що у світі зберігається необхідність підвищення ефективності реабілітації осіб з наслідками травм і захворювань дистальних відділів верхніх кінцівок за рахунок створення індивідуальних програм ФТ, об'єктивізації критеріїв обмеження життєдіяльності, а також їх впровадження в практичну роботу лікувальних, реабілітаційних, санаторно-курортних закладів.

Пацієнти $з$ травмами і захворюваннями китиці є одним з найчисленніших контингентів реабілітаційних установ $[9,11]$. Це обумовлено тією величезною роллю, яку відіграє китиця в побуті, самообслуговуванні, повсякденній та професійній діяльності. Найважливішою функцією китиці є рухова - здатність до захоплень і маніпуляцій, яка найчастіше страждає в результаті травми або захворювання кисті [12].

Недосконалість реабілітаційної системи та незавершеність іiі реформування в Україні призводить до того, що повноцінну ФТ під час іммобілізації кісток внаслідок переломів (яка могла б прискорити темп функціонального одужання) пацієнти проходять відносно зрідка, особливо якщо перебувають в цей період у стаціонарні $[9,11]$. Тому фізичний терапевт часто вперше контактує $з$ пацієнтом саме після зняття гіпсової пов'язки, корегуючи постіммобілізаційний синдром у вигляді контрактури суглобів, атрофії м'язів, тощо. 
Таблиця 1

Динаміка функціонального стану передпліччя та китиці під впливом програми ФТ за результатами Тесту дослідження функцій руки (Action Research Arm Test), $(\bar{x} \pm \mathbf{S})$

\begin{tabular}{|c|c|c|c|c|c|c|}
\hline \multirow[t]{3}{*}{ Час виконання тесту, с } & \multicolumn{3}{|c|}{ ГП (n=27), тестована рука } & \multicolumn{3}{|c|}{ ОГ (n=29), тестована рука } \\
\hline & \multirow[b]{2}{*}{ здорова } & \multicolumn{2}{|c|}{ хвора } & \multirow[b]{2}{*}{ здорова } & \multicolumn{2}{|c|}{ хвора } \\
\hline & & \begin{tabular}{|c|} 
первинне \\
обстеження
\end{tabular} & $\begin{array}{c}\text { повторне } \\
\text { обстеження }\end{array}$ & & до ФТ & після ФТ \\
\hline \multicolumn{7}{|c|}{ Кульове захоплення - взяти й утримати у руці } \\
\hline $\begin{array}{l}\text { дерев'яний } \\
\text { грані } 10 \text { см }\end{array}$ & $2,70 \pm 0,09$ & $\mid 1,85 \pm 0,10^{*}$ & $1,96 \pm 0,10^{*}$ & $2,72 \pm 0,08$ & $1,86 \pm 0,09 *$ & $2,34 \pm 0,09^{*} \bullet \circ$ \\
\hline $\begin{array}{|lll|}\text { дерев'яний кубик } & 3 & \text { довжиною } \\
\text { грані 2,5 см } & & \\
\end{array}$ & $2,81 \pm 0,07$ & $\mid 1,81 \pm 0,13 *$ & $2,00 \pm 0,13^{*}$ & $2,83 \pm 0,03$ & $1,79 \pm 0,12^{*}$ & $2,59 \pm 0,09^{* \circ} \bullet$ \\
\hline \begin{tabular}{|l} 
дерев'яний \\
rрані 5 см
\end{tabular} кубик 3 довжиною & $2,89 \pm 0,06$ & $1,85 \pm 0,15^{*}$ & $2,04 \pm 0,11 *$ & $2,90 \pm 0,06$ & $1,83 \pm 0,13^{*}$ & $2,69 \pm 0,09^{\circ} \bullet$ \\
\hline $\begin{array}{llll}\text { дерев'яний кубик } & 3 & \text { довжиною } \\
\text { грані 7,5 cм }\end{array}$ & $2,78 \pm 0,0$ & $1,84 \pm 0,14^{*}$ & $2,00 \pm 0,10^{*}$ & $2,79 \pm 0,08$ & $1,86 \pm 0,13^{*}$ & $2,62 \pm 0,09^{\circ} \bullet$ \\
\hline дерев'яну кулю діаметром 7,5 см & $2,78 \pm 0,08$ & $1,74 \pm 0,12 *$ & $2,04 \pm 0,11 * \circ$ & $2,90 \pm 0,06$ & $1,79 \pm 0,11^{*}$ & $2,66 \pm 0,09^{* \circ} \bullet$ \\
\hline камінь розмірами 10 × 2,5 × 1 cм & $2,85 \pm 0,07$ & $1,74 \pm 0,14 *$ & $1,96 \pm 0,13 *$ & $2,86 \pm 0,06$ & $1,76 \pm 0,13^{*}$ & $2,62 \pm 0,09 * \circ \bullet$ \\
\hline Середній бал за субтест & $2,82 \pm 0,06$ & $1,81 \pm 0,09 *$ & $2,00 \pm 0,08^{*}$ & $2,83 \pm 0,06$ & $1,82 \pm 0,08^{*}$ & $2,59 \pm 0,06^{* \circ} \bullet$ \\
\hline \multicolumn{7}{|c|}{ Циліндричне захоплення - взяти й утримати в руці } \\
\hline $\begin{array}{l}\text { перелити воду зі склянки у склян- } \\
\text { ку }\end{array}$ & $2,63 \pm 0,09$ & \begin{tabular}{|l|}
$1,67 \pm 0,10^{*}$ \\
\end{tabular} & $2,19 \pm 0,09 * 0$ & $2,69 \pm 0,09$ & $1,66 \pm 0,10^{*}$ & $2,41 \pm 0,09$ \\
\hline $\begin{array}{l}\text { трубку діаметром } 2 \text { см і довжи- } \\
\text { ною } 20 \mathrm{~cm}\end{array}$ & $2,85 \pm 0,07$ & $1,70 \pm 0,10^{*}$ & $2,22 \pm 0,10^{* \circ}$ & $2,90 \pm 0,06$ & $1,69 \pm 0,10^{*}$ & $2,66 \pm 0,09^{* \circ} \bullet$ \\
\hline $\begin{array}{l}\text { трубку діаметром } 1 \text { см і довжи- } \\
\text { ною } 16 \text { см }\end{array}$ & $2,81 \pm 0,07$ &, $11^{*}$ & 2,30 & $2,83 \pm 0,07$ &, $11^{*}$ & $08^{\circ} \bullet$ \\
\hline $\begin{array}{l}\text { шайбу діаметром } 3,5 \text { см, накруче- } \\
\text { ну на болт }\end{array}$ & $2,85 \pm 0,07$ & $1,36 \pm 0,13 *$ & $2,33 \pm 0,10 * 0$ & $2,86 \pm 0,06$ & $1,62 \pm 0,12^{*}$ & $2,69 \pm 0,09^{\circ} \bullet$ \\
\hline Середній бал за субтест & $2,79 \pm 0,06$ & $1,96 \pm 0,07 *$ & 2,26 & 06 & 1,6 & 2,6 \\
\hline \multicolumn{7}{|c|}{ Щипкове захоплення - взяти й утримати пальцями кульку } \\
\hline $\begin{array}{l}\text { першим і четвертим - діаметром } 6 \\
\text { мм }\end{array}$ & $2,22 \pm 0,08$ & $\mid 1,67 \pm 0,10^{*}$ & $2,00 \pm 0,09 * 0$ & $2,21 \pm 0,08$ & $1,72 \pm 0,11^{*}$ & $2,31 \pm 0,09^{\circ} \bullet$ \\
\hline $\begin{array}{l}\text { першим і другим - діаметром 1,5 } \\
\text { см }\end{array}$ & $2,67 \pm 0,09$ & $1,85 \pm 0,14^{*}$ & $2,04 \pm 0,13 *$ & $2,59 \pm 0,09$ & $1,93 \pm 0,13 *$ & $2,59 \pm 0,09^{\circ} \bullet$ \\
\hline першим і третім -діаметром 6 мм & $2,56 \pm 0,10$ & $1,93 \pm 0,14^{*}$ & $2,07 \pm 0,14^{*}$ & $2,62 \pm 0,09$ & $1,97 \pm 0,13^{*}$ & $2,62 \pm 0,09^{\circ} \bullet$ \\
\hline \begin{tabular}{|lll} 
першим i другим - діаметром \\
6 мм \\
\end{tabular} & $2,78 \pm 0,08$ & $1,85 \pm 0,15^{*}$ & $2,15 \pm 0,11^{*}$ & $2,69 \pm 0,09$ & $1,86 \pm 0,14^{*}$ & $2,55 \pm 0,09^{\circ} \bullet$ \\
\hline $\begin{array}{l}\text { першим і третім - діаметром } 1,5 \\
\text { см }\end{array}$ & $2,63 \pm 0,08$ & $1,89 \pm 0,12 *$ & $2,07 \pm 0,10^{*}$ & $2,66 \pm 0,09$ & $1,93 \pm 0,12 *$ & $2,66 \pm 0,12^{\circ} \bullet$ \\
\hline $\begin{array}{ll}\text { першим і четвертим -діаметром } \\
1,5 \text { см }\end{array}$ & $2,59 \pm 0,09$ & $1,85 \pm 0,14 *$ & $2,00 \pm 0,10^{*}$ & $2,52 \pm 0,09$ & $1,90 \pm 0,13^{*}$ & $2,52 \pm 0,09^{\circ} \bullet$ \\
\hline Середній бал за субтест & $2,57 \pm 0,05$ & $1,84 \pm 0,09^{*}$ & $2,06 \pm 0,09 *$ & $2,55 \pm 0,06$ & $1,89 \pm 0,09 *$ & $2,54 \pm 0,06^{\circ} \bullet$ \\
\hline \multicolumn{7}{|l|}{ Грубі рухи - долоню руки } \\
\hline покласти на потилицю & $2,74 \pm 0,08$ & $2,59 \pm 0,09$ & $2,63 \pm 0,09$ & $2,76 \pm 0,08$ & $2,62 \pm 0,09$ & $2,66 \pm 0,09$ \\
\hline покласти на верхівку голови & $2,89 \pm 0,06$ & $2,81 \pm 0,07$ & $2,85 \pm 0,07$ & $2,90 \pm 0,06$ & $2,83 \pm 0,07$ & $2,86 \pm 0,06$ \\
\hline піднести до рота & $2,93 \pm 0,06$ & $2,78 \pm 0,08$ & $2,81 \pm 0,07$ & $2,90 \pm 0,06$ & $2,79 \pm 0,08$ & $2,83 \pm 0,07$ \\
\hline Середній бал за субтест & $2,85 \pm 0,06$ & $2,73 \pm 0,07$ & $2,76 \pm 0,06$ & $2,85 \pm 0,06$ & $2,75 \pm 0,07$ & $2,78 \pm 0,06$ \\
\hline Середній бал за тест & $2,81 \pm 0,03$ & $2,03 \pm 0,05^{*}$ & $2,22 \pm 0,05^{* \circ}$ & $2,76 \pm 0,03$ & $2,03 \pm 0,04 *$ & $2,63 \pm 0,03^{* \circ} \bullet$ \\
\hline
\end{tabular}

Примітки: * - статистична значуща різниця відносно відповідного показника здорової руки $(\mathrm{p}<0,05)$;

○ - статистична значуща різниця відносно відповідного показника травмованої руки до ФТ (p<0,05);

• - статистична значуща різниця відносно відповідного показника ГП (p<0,05) 
Таблиця 2

Динаміка функціонального стану передпліччя та китиці під впливом програми ФТ за результатами

Тесту функції руки Френчай (Frenchay Arm Test), $(\bar{x} \pm \mathrm{S})$

\begin{tabular}{|c|c|c|c|c|}
\hline \multirow[t]{2}{*}{ Тести } & \multicolumn{2}{|c|}{ ГП } & \multicolumn{2}{|c|}{$\mathrm{O \Gamma}$} \\
\hline & $\begin{array}{c}\text { первинне } \\
\text { обстеження }\end{array}$ & $\begin{array}{c}\text { кінцеве об- } \\
\text { стеження }\end{array}$ & до ФТ & після ФТ \\
\hline $\begin{array}{l}\text { Утримати лінійку, з іiї допомогою накрес- } \\
\text { лити лінію, тримаючи олівець в нетрав- } \\
\text { мованій руці }\end{array}$ & $0,48 \pm 0,10$ & $0,63 \pm 0,09^{\circ}$ & $0,52 \pm 0,09$ & $0,86 \pm 0,06^{\circ} \bullet$ \\
\hline $\begin{array}{l}\text { Узяти в руку циліндр діаметром } 12 \text { мм і } \\
\text { довжиною } 5 \text { см, поставлений вертикально } \\
\text { на відстані } 15-30 \text { см від краю столу; під- } \\
\text { няти його на висоту близько } 30 \text { см та } \\
\text { опустити на місце }\end{array}$ & $0,52 \pm 0,10$ & $0,59 \pm 0,09$ & $0,48 \pm 0,09$ & $0,79 \pm 0,08^{\circ} \bullet$ \\
\hline $\begin{array}{l}\text { Узяти склянку, наполовину наповнену } \\
\text { водою і поставлену на відстані 15-30 см } \\
\text { від краю столу. Надпити води і поставити } \\
\text { склянку на місце, не розплескавши при } \\
\text { цьому воду }\end{array}$ & $0,55 \pm 0,09$ & $0,59 \pm 0,09$ & $0,55 \pm 0,09$ & $0,76 \pm 0,08^{\circ} \bullet$ \\
\hline $\begin{array}{l}\text { Зняти, а потім вчепити на попереднє міс- } \\
\text { це прищіпку для білизни, укріплену на } \\
\text { вертикальному кілочку довжиною } 15 \text { см і } \\
\text { діаметром } 10 \text { мм (що стоїть на квадратній } \\
\text { дощечці 10x10 см, розташованій на відс- } \\
\text { тані } 15-30 \text { см від краю столу) }\end{array}$ & $0,48 \pm 0,10$ & $0,59 \pm 0,09$ & $0,45 \pm 0,09$ & $0,83 \pm 0,07^{\circ} \bullet$ \\
\hline $\begin{array}{l}\text { Причесати (або імітувати причісування) } \\
\text { волосся на маківці, на потилиці, } 3 \text { правого } \\
\text { та лівого боків }\end{array}$ & $0,67 \pm 0,09$ & $0,74 \pm 0,08$ & $0,69 \pm 0,09$ & $0,90 \pm 0,06^{\circ} \bullet$ \\
\hline Загальний бал & $2,74 \pm 0,22$ & $3,15 \pm 0,30$ & $2,69 \pm 0,20$ & $4,14 \pm 0,19^{\circ} \bullet$ \\
\hline
\end{tabular}

Примітки: ${ }^{\circ}$ - статистична значуща різниця відносно показника травмованої руки до ФТ $(\mathrm{p}<0,05)$;

- - статистична значуща різниця відносно відповідного показника ГП $(\mathrm{p}<0,05)$

Існуючі програми фізичної терапії при травмах дистальних відділів верхньої кінцівки приділяють увагу переважно відновленню дрібної моторики пальців $[6,7,8,18]$. В той же час, ПЗС дозволяє китиці, як виконавчому сегменту, приймати оптимальне положення для хапальної функції. За рахунок ПЗС та ротаційного механізму передпліччя китиця має два ступені свободи, а, з урахуванням повороту передпліччя навколо поздовжньої осі, iї можна орієнтувати під будь-яким потрібним кутом для забезпечення захоплення та утримання предмета. Тому пошук нових шляхів для відновлення рухомості ПЗС є актуальним напрямком реабілітації.

Частим недоліком вже існуючих програм реабілітації є зловживання пасивними методиками (зокрема, преформованими фізичними факторами) 3 недоказаною клінічною ефективністю $[11,21]$, або, навпаки, складними апаратними методиками, недоступними багатьом хворим [3, 7, 23].

Актуальним питанням залишається оцінювання фізичним терапевтом характеру і ступеня дисфункції верхньої кінцівки з позицій МКФ на початку та впродовж реабілітації пацієнта 3 постіммобілізаційною контрактурою ПЗС, оскільки існуючі програми ФТ цього фактично не розглядають $[10,11,14,15$, 21]. Така оцінка необхідна для визначення короткота довгострокових цілей ФТ, об'єктивізації динаміки відновлення, прогнозування результату, корекції програм реабілітації. Ще більшого значення набуває оцінка результатів реабілітації в умовах можливості впровадження страхової медицини, розвитку аудиту медичної діяльності, перспективами конкурентної діяльності та боротьби за пацієнта лікувальних та реабілітаційних закладах в рамках реформи спеціалізованої медичної допомоги.

Вважаємо, що у мультидисциплінарній реабілітаційній бригаді, що працює $з$ пацієнтом 3 посттравматичними та постіммобілізаційними контрактурами, саме фізичному терапевтові потрібно відводити провідне місце. Він здійснює практичне відновлення структури, функцій та активності, які мають найбільший відсоток у порушенні стану здоров'я цих пацієнтів.

Новим поглядом на тести, використані у дослідженні, $\epsilon$ наступне. Вони зручними 3 точки зору того, що дають не тільки цифрове вираження ступеня порушення, але й виявляють індивідуальні слабкі сторони рухової функції китиці, що зручно для встановлення індивідуальних короткотермінових цілей реабілітації та створення програми кінезітерапії на основі функціонального тренування.

Деякі незручності можуть виникнути в процесі підготовки спеціальних предметів для представленого тестування, але їх можна обрати серед реабілітаційних ерготерапевтичних приладів, бізі-бордів кабінету ерготерапії, дитячих конструкторів або лег- 
ко виготовити або підібрати самостійно з підручних засобів.

Дані, отримані при проведені визначення прикладного індивідуального виду та ступеня функціональних порушень, можуть бути використані не тільки для розробки програм фізичної терапії, але й ерготерапії у випадку неможливості досягнення повного відновлення функцій передпліччя та китиці.

\section{Висновки:}

1. У пацієнтів із постіммобілізаційною контрактурою променево-зап'ясткового суглобу виявлені значні порушення функціонування передпліччя та китиці, що визначено за допомогою тестів дослідження функцій руки та Франчай.

2. Найбільш погіршеними рухами внаслідок постіммобілізаційної контрактури виявились кульове, циліндричне та щипкове захоплення.

3. Розроблена комплексна програма фізичної терапії, створена на основі принципів Міжнародної класифікації функціонування із застосуванням функціонального тренування із використанням китичних тренажерів, теплих вологих компресів, постізометричної релаксації, масажу, електростимуляції, кінезіологічного тейпування продемонструвала статистично значуще кращий вплив на показники функціонування передпліччя та китиці на основі результатів тестів дослідження функцій руки та Франчай у порівнянні із загальною поліклінічною реабілітаційною програмою.

\section{References:}

1. Abramov VV, Kanyuka EV, Nekhanevych OB. Analyz struktury povrezhdenyy $u$ patsyentov $s$ zastarelymy travmamy dystal'nykh otdelov verkhnykh konechnostey. Visnyk problem biolohiyi i medytsyny. 2014; 3(111):101-5. https://vpbm.com.ua/vpbm-2014$03-2 / 6711$

2. Albanese GA, Marini F, Taglione E, Gasparini C, Grandi S, Pettinelli F, et al. Assessment of human wrist rigidity and pain in post-traumatic patients. International Conference on Rehabilitation Robotics. Proceedings. 2019; Jun;2019:89-94. DOI: 10.1109/ICORR.2019.8779508.

3. Andrade-Silva FB, Rocha JP, Carvalho A, Kojima KE, Silva JS. Influence of postoperative immobilization on pain control of patients with distal radius fracture treated with volar locked plating: A prospective, randomized clinical trial. Injury. 2019; Feb;50(2):386-391.DOI:10.1016/j.injury.2018.12.001.

4. Bazancir Z, Firat T. A potential factor in the pathophysiology of lateral epicondylitis: The long sarcomere length of the extensor carpi radialis brevis muscle and implications for physiotherapy. Medical hypotheses. 2019; Sep;130:109278. DOI: 10.1016/j.mehy.2019.109278. Epub 2019 Jun 12.

5. Belova AN, Shchepetov ON. Shkaly, testy i oprosniki v meditsinskoy reabilitatsii. Moskva: Antidor, 2002.

6. Bilinskyy PI, Drobotun OV, Palamar DI, Tykhonov OA, Kravchenya DV. Do pytannya likuvannya perelomiv promenevoyi kistky $\mathrm{v}$ typovomu mistsi. Travma. 2016; 17(6):20-4. DOI: 10.22141/16081706.6.17.2016.88613
7. Crowe CS, Massenburg BB, Morrison SD, Chang J, Friedrich JB, Abady GG, et al. Global trends of hand and wrist trauma: a systematic analysis of fracture and digit amputation using the Global Burden of Disease 2017 Study. Injury prevention : journal of the International Society for Child and Adolescent Injury Prevention. 2020; Mar 13. pii: injuryprev-2019043495. DOI: 10.1136/injuryprev-2019-043495.

8. Giummarra MJ3, Cameron PA, Ponsford J, Ioannou L, Gibson SJ, Jennings PA, Georgiou-Karistianis N. Return to Work After Traumatic Injury: Increased Work-Related Disability in Injured Persons Receiving Financial Compensation is Mediated by Perceived Injustice. Journal of Occupational Rehabilitation. 2017; Jun;27(2):173-185. DOI: 10.1007/s10926-0169642-5.

9. Hertsyk A. Teoretyko-metodychni osnovy fizychnoyi reabilitatsiyi/ fizychnoyi terapiyi pry porushennyakh diyal'nosti oporno-rukhovoho aparatu. Lviv: LDUFK, 2018.

10. Kachanathu SJ, Alenazi AM, Hafez AR, Algarni AD, Alsubiheen AM. Comparison of the effects of shortduration wrist joint splinting combined with physical therapy and physical therapy alone on the management of patients with lateral epicondylitis. European journal of physical and rehabilitation medicine. 2019; Aug;55(4):488-493. DOI: 10.23736/S1973-9087.19.05280-8.

11. Kanyuka YEV, Abramov VV, Nekhanevych OB. Aktualnist zastosuvannya zasobiv fizychnoyi reabilitatsiyi u vidnovnomu likuvanni khvorykh ta invalidiv $\mathrm{z}$ travmamy verkhnikh kintsivok (ohlyady literatury). Visnyk problem biolohiyi i medytsyny. 2014; (106):11-6. https://vpbm.com.ua/vpbm-2014$03-2 / 6711$

12. Kapandzhi AI. Verkhnyaya konechnost'. Fiziologiya sustavov. T. 1. Moskva; Eksmo, 2017.

13. Kılıç S, Adıyaman S, Sezer F, Cantürk G. Upper Extremity Injuries Due to Work Accidents in Work Accident Disability Assessments: Three Case Reports. The Bulletin of Legal Medicine. 2017; 22(1):72-5. DOI: 10.17986/blm.2017127145.

14. Mayland EC, Hay-Smith EJ, Treharne GJ. Recoveryrelated anxiety and disability following upper limb injury: the importance of context. Disability and Rehabilitation. 2015; 37(19):1753-9. DOI: 10.3109/09638288.2014.976719.

15. Mukin VM. Fizychna reabilitatsiya v travmatolohiyi: monohrafiya L'viv, LDUFK, 2015.

16. Naumenko LYU, Ipatov AV, Zub TO, Mametyev AO. Stan invalidnosti vnaslidok travm verkhnoyi kintsivky v Ukrayini za 2017 rik. Travma. 2018; 19(4):9-14. DOI: 10.22141/1608-1706.4.19. 2018.142100

17. O'Sullivan ST, Schmitz T. Physical Rehabilitation: assessment and Treatment. Philadelphia: F.A. Davis; 2016. 787 p.

18. Sabapaty SR. Treatment of mutilating hand injurues: An international perspective. Hand Clinics. 2016; 32(4):435-602. DOI /10.1016/S0749-0712(16)300919. 
19. Sposib kompleksnoyi reabilitatsiyi khvorykh z kontrakturamy promenevo-zapyastkovykh suhlobiv pislya znyattya immobilizatsiyi: Patent na korysnu model №134145 Ukrayina: MPK A61F 7/02. № u 2018 08710; zayavl. 14.08.2018; opubl. 10.05.2019, Byul. № 9.

20. Unifikovanyy klinichnyy protokol pervynnoyi, vtorynnoyi (spetsializovanoyi) ta tretynnoyi (vysokospetsializovanoyi) medychnoyi dopomohy. Perelomy dystal'noho metaepifiza promenevoyi kistky. Litopys travmatolohiyi ta ortopediyi. 2018; 12:178-97.

21. Valeyev MM, Biktasheva EM. Rannyaya razrabotka luchezapyastnogo sustava pri zakrytom perelome distalnogo metaepifiza luchevoy kosti. Fizioterapiya, balneologiya i reabilitatsiya. 2017; 16(4):216-218. DOI: http://dx.doi.org/10.18821/1681-3456-2017-164-216-218

22. Wade DT. Measurement in neurological rehabilitation. Current Opinion in Neurology. 1992; 5(5):682-6.

23. Wollstein R, Harel H, Lavi I, Allon R, Michael D. Postoperative Treatment of Distal Radius Fractures Using Sensorimotor Rehabilitation. Journal of wrist surgery. 2019; Feb;8(1):2-9. DOI: 10.1055/s-00381672151.

\section{УДК 616-001.5+615.8}

\section{АНАЛИЗ ВЛИЯНИЯ ПРОГРАММЫ ФИЗИ- ЧЕС КОЙ ТЕРАПИИ НА ПОКАЗАТЕЛИ ФУНКЦИОНИРОВАНИЯ ПРЕДПЛЕЧЬЯ И КИСТИ У БОЛЬНЫХ С ПОСТИММОБИЛИ- ЗАЦИОННЫМИ КОНТРАКТУРАМИ ЛУЧЕЗАПЯСТНОГО СУСТАВА}

\section{В.М. Бырчак}

Прикарпатский национальный университет имени Василия Стефаника, кафедра физической терапии, эрготерапии, г. Ивано-Франковск, Украина, ORCID ID: 0000-0001-8424-4923,

e-mail:vmbyrchak@gmail.com

Цели: определение эффективности разработанной программы физической терапии по результатам параметров функционирования предплечья и кисти у больных с постиммобилизационными контрактурами лучезапястного сустава (ЛЗС).

Методы. Обследовано 56 человек с постиммобилизационной контрактурой ЛЗС. Они были разделены на две группы: контрольную (занимались по принципам поликлинической реабилитации) и группу сравнения (занимались по разработанной программе физической терапии -комбинация теплого влажного компресса в сочетании с постизометрической релаксацией мышц предплечья и кисти; массаж кисти, ЛЗС, предплечья, плеча; электростимуляция; функциональная тренировка предплечья, кисти; лечение положением с помощью динамических ортезов; кинезиологическое тейпирование).

Эффективность программы оценивали в динамике сравнения состояния здоровой и травмиро- ванной рук по результатам Теста исследования функций руки (Action Research Arm Test) и Теста для руки Френчай (Frenchay Arm Test).

Результаты. При определении динамики субтестов Теста исследования функций руки определено статистически значимое улучшение параметров основной группы относительно исходных показателей и данных группы сравнения $(\mathrm{p}<0,05)$. По субтестам цилиндрического и щипкового захвата удалось достичь величин здоровой руки. Пациенты основной группы также продемонстрировали улучшение функционирования руки по сравнению с исходным тестированием и параметрами группы сравнения по всем задачам Теста Френчай $(\mathrm{p}<0,05)$.

Выводы. Разработана комплексная программа физической терапии показала статистически значимое лучшее влияние на показатели функционирования предплечья и кисти на основе результатов тестов исследования функций руки и Франчай по сравнению с поликлинической реабилитационной программой.

Ключевые слова: реабилитация, перелом кости, верхняя конечность.

\section{UDC 616-001.5+615.8 \\ ANALYSIS OF THE FOREARM AND HAND \\ FUNCTIONING IN PATIENTS WITH POST- IMMOBILIZATION WRIST JOINT CONTRAC- TURE}

\author{
V.M. Byrchak \\ Vasyl Stefanyk Precarpathian National University, \\ Department of Physical Therapy, Ergotherapy, \\ Ivano-Frankivsk, Ukraine, \\ ORCID ID: 0000-0001-8424-4923, \\ e-mail:vmbyrchak@gmail.com
}

Abstract. Objectives: to determine the effectiveness of the developed program of physical therapy on the results of the parameters of the functioning of the forearm and wrist in patients with postmobilization contractures of the wrist joint.

Methods. 56 people with post immobilization contracture of the wrist joint were examined. Patients were divided into two groups: a comparison group (29 people), in which a rehabilitation program was conducted according to the principles of outpatient rehabilitation. The main group (27 people) consisted of people undergoing rehabilitation according to the developed physical therapy program.

The developed program lasted 2 months, was introduced during the outpatient rehabilitation phase and consisted of the following components:

- The author's combination of a warm moist compress in combination with post-isometric relaxation of the muscles of the forearm and hand;

- Massage of the wrist, wrist joint, forearm, shoulder

- Electrical stimulation

- Kinesiotherapy: functional training of the muscles of the forearm, hand; 
- Position treatment using individual dynamic orthoses for the wrist joint;

- Kinesio taping of the forearm and hand.

To determine the degree of functional impairment, an Action Research Arm Test and a French Arm Test were performed. The effectiveness of the program was evaluated in dynamics before and after the introduction of the results of comparing the state of a healthy and injured upper limb in each patient.

Results. When determining the functional state of the forearm and hand according to the results of the Action Research Arm Test, it was determined that the subtest "Rough hand movements" ( $p<0.05$ relative to all samples of a healthy limb) was characterized by the least disturbance in both groups.

All other components of the test were spherical, cylindrical, plucked grips were significantly worsened relative to the corresponding index of a healthy hand ( $\mathrm{p}>$ $0.05)$.

Examination using the French Arm Test revealed low functional capabilities of the distal parts of the injured upper limbs, which was manifested in complications or inability to complete all test tasks.

Repeated examination of patients with post immobilization contracture of the wrist joint showed signif- icant advantages of the created physical therapy program.

So, when determining the dynamics of subtests of the Action Research Arm Test, a statistically significant improvement in the parameters of the main group was determined not only relative to the initial indicators, but also the data of the comparison group $(p<0.05)$. The best dynamics was characterized by subtests of cylindrical and plucked grips, according to which it was possible to achieve the values of a healthy hand.

The dynamics of the results of the French Arm Test also showed the advantage of the developed rehabilitation program. Patients of the main group showed a statistically significant improvement in the functioning of the arm compared to the initial test and the parameters of the comparison group for all tests performed ( $p$ $<0.05)$.

Conclusions. A comprehensive physical therapy program was developed that found a statistically significant better effect on the functioning of the forearm and hand based on the results of tests of the functions of the arm and Franchay compared to the outpatient rehabilitation program.

limb.

Keywords: rehabilitation, bone fracture, upper 